\title{
Role of Platelet Fibrinogen in the Reactions of Platelets to Thrombin*
}

\author{
Edward E. Morse, $\dagger$ Dudley P. Jackson, and C. Lockard Conley \\ (From the Department of Medicine, The Johns Hopkins University and Hospital, \\ Baltimore, Md.)
}

Washed human blood platelets contain a clottable protein that is similar to, if not identical with, plasma fibrinogen (1-4). After incubation with trypsin under appropriate conditions, platelets remain morphologically intact but no longer contain clottable protein (5). Trypsinized platelets, unlike normal platelets, are not aggregated by fresh serum or by a solution of thrombin and calcium chloride. When resuspended in plateletfree plasma or in a buffered solution of fibrinogen containing glucose, trypsinized platelets produce retraction of clots formed by thrombin; during the formation of the clot and its subsequent retraction, trypsinized platelets aggregate and undergo the usual changes of viscous metamorphosis (5). These observations suggest that fibrinogen on the surface of platelets is involved in the reaction of platelets to thrombin. This reaction does not consist simply of the coagulation of fibrinogen with entrapment of platelets in the fibrin mesh. Under usual conditions divalent cations are required for thrombin-induced platelet aggregation but not for clotting of fibrinogen $(5,6)$. Electron photomicrographs of platelet aggregates show no striated fibrin strands between adherent

\footnotetext{
* Submitted for publication October 2, 1964; accepted January 21, 1965.

These investigations were carried out under contract AT(30-1) 1208 between the Atomic Energy Commission and The Johns Hopkins University and were supported in part by research grant HE-01601 from the National Heart Institute, research career program award AM-K33779 , and graduate training grant T1 AM-5260 from the National Institute of Arthritis and Metabolic Diseases.

Presented in part at the meeting of the Federation of American Societies for Experimental Biology in April 1963, and abstracted in Fed. Proc. 1963, 22, 505.

$\dagger$ Work done in part during the tenure of U. S. Public Health Service special fellowship CSP 18,037 from the National Cancer Institute. Address requests for reprints to Dr. Edward E. Morse, Hematology Division, The Johns Hopkins Hospital, Baltimore, Md. 21205.
}

platelets (7). Accordingly, additional studies were undertaken using enzymes known to alter plasma fibrinogen to define more precisely the role of platelet fibrinogen in the reaction of platelets to thrombin.

\section{Methods}

Platelet-rich plasma was obtained from human donors by plasmapheresis (8) with plastic equipment ${ }^{1}$ or by centrifugation of venous blood at $50 \mathrm{~g}$ for 30 minutes at room temperature. Glassware with which platelets had contact was coated with silicone. ${ }^{2}$ One-tenth volume of a $1.5 \%$ solution of the disodium salt of EDTA was used as anticoagulant. Platelet-free plasma was obtained by centrifugation at $22,000 \mathrm{~g}$ for 10 minutes at $4^{\circ} \mathrm{C}$. Platelets were sedimented from 20 to $40 \mathrm{ml}$ of platelet-rich plasma by centrifugation at $1,900 \mathrm{~g}$ for 10 minutes at room temperature. The sedimented platelets were resuspended in $5 \mathrm{ml}$ of EDTA Tris-buffered saline (equal volumes 0.3 $\mathrm{M}$ Tris solution and $0.9 \%$ sodium chloride, $\mathrm{pH}$ adjusted to 7.5 with $2 \mathrm{~N}$ hydrochloric acid and containing EDTA, $0.0013 \mathrm{M})$. The platelets were washed twice by centrifugation at $4,700 \mathrm{~g}$ for 5 minutes at $4^{\circ} \mathrm{C}$ and resuspension in $5 \mathrm{ml}$ of the EDTA Tris-buffered saline. They were then resuspended in EDTA Tris-buffered saline, and various amounts of one of the following proteolytic enzymes were added: bovine thrombin, ${ }^{3}$ trypsin, ${ }^{4}$ plasminogen prepared by the modified Kline method (9) from human plasma Fraction III 5 and activated with streptokinase, ${ }^{6}$ spontaneously activated plasmin in $50 \%$ glycerol, ${ }^{7} \alpha$-chymotrypsin, ${ }^{8}$ papain, ${ }^{9}$ or carboxypepti-

\footnotetext{
1 Fenwal, Framingham, Mass.

2 G.E. silicone SC-87 dri-film.

3 Thrombin, topical, Parke, Davis, Detroit, Mich.

4 Twice recrystallized, salt-free trypsin, Worthington Biochemical Corp., Freehold, N. J.

5 Cohn Fraction III human plasma, Lederle Laboratories, Pearl River, N. Y.

- Varidase 2200-76, Lederle Laboratories, Pearl River, N. Y. The activated plasminogen had an activity of 30 casein $U$ per $\mathrm{mg}$.

7 Forty-four caseinolytic U per $\mathrm{ml}$, kindly supplied by Dr. Alan Johnson, New York, N. Y. This preparation was dialyzed against $0.15 \mathrm{M} \mathrm{KCl}(\mathrm{pH} \mathrm{7.3)}$ to remove the
} 
dase. ${ }^{10}$ The platelets were incubated with the enzyme for 10 minutes at $37^{\circ} \mathrm{C}$ in a final volume of $5 \mathrm{ml}$. During incubation with thrombin an EDTA concentration of $0.008 \mathrm{M}$ was used to inhibit aggregation. In some experiments inhibitors were added following the incubation to assure cessation of enzyme activity. $\epsilon$-Aminocaproic acid (EACA) ${ }^{11}$ or a bovine lung inhibitor ${ }^{12}$ was used to inhibit plasmin, soy bean trypsin inhibitor ${ }^{13}$ to inhibit trypsin, and heparin ${ }^{14}$ to inhibit thrombin. The platelets then were immediately centrifuged in the cold and washed once with and resuspended in $5 \mathrm{ml}$ EDTA Trisbuffered saline. Samples of these suspensions were used for the following studies.

Aggregation. Five-tenths $\mathrm{ml}$ was centrifuged at 1,800 $g$ for 5 minutes, and the platelets were suspended in 0.2 $\mathrm{ml}$ Tris-buffered saline without EDTA in siliconized tubes to which was added $0.05 \mathrm{ml}$ of a solution of thrombin, $100 \mathrm{U}$ per $\mathrm{ml}$ in $0.025 \mathrm{M} \mathrm{CaCl}$. The tubes were gently agitated and observed for gross and microscopic aggregation. Aggregation was graded as follows: 0, no aggregation; $1+$, few small clumps ; $2+$, numerous small clumps; $3+$, many large clumps; $4+$, very large clumps with few free platelets.

Clot retraction. Five-tenths $\mathrm{ml}$ was centrifuged at $1,800 \mathrm{~g}$ for 5 minutes, and the platelets were resuspended in $0.3 \mathrm{ml}$ platelet-free plasma in siliconized tubes to which was added $0.1 \mathrm{ml}$ of a solution of thrombin, 100 $\mathrm{U}$ per $\mathrm{ml}$ in $0.025 \mathrm{M} \mathrm{CaCl}_{2}$. The tubes were inverted once and incubated at $37^{\circ} \mathrm{C}$. Clot retraction was graded at 2 hours and again at 24 hours : 0 , no retraction; $1+$, separation of clot from wall of tube; $2+$, clot retracted to half the volume in the tube; $3+$, clot retracted to onequarter of the volume in the tube; and $4+$, small retracted clot similar to control. In experiments with plasmin-treated platelets, $0.025 \mathrm{ml}$ of EACA was added to the plasma before the addition of thrombin and calcium.

Clottable protein. Three $\mathrm{ml}$ was centrifuged at 22,000 $g$ for 10 minutes, and the platelets were frozen and thawed five times in $0.2 \mathrm{ml}$ of a $0.9 \%$ solution of sodium chloride with alcohol-dry ice. The suspension was centrifuged at $22,000 \mathrm{~g}$ for 10 minutes and the supernatant tested for clottable protein by the addition of $0.1 \mathrm{ml}$ of a solution of

glycerol and was concentrated to the original volume by negative pressure.

$8 \alpha$-Chymotrypsin $3 \times$ crystallized, Worthington Biochemical Corp., Freehold, N. J.

9 Papain, twice crystallized suspension in $0.05 \mathrm{M}$ sodium acetate, Worthington Biochemical Corp., Freehold, N. J.

10 Carboxypeptidase diisopropyl fluorophosphate, $3 \times$ crystallized, Worthington Biochemical Corp., Freehold, N. J.

11 EACA, $250 \mathrm{mg}$ per ml, Lederle Laboratories, Pearl River, N. Y.

12 Bayer $3380 \mathrm{RK}$ or A 128, FBA Pharmaceuticals, New York, N. Y.

13 Worthington Biochemical Corp., Freehold, N. J.

14 Heparin sodium, 10,000 U per $\mathrm{ml}$, Lederle Laboratories, Pearl River, N. Y. thrombin, $100 \mathrm{U}$ per $\mathrm{ml}$ in $0.025 \mathrm{M} \mathrm{CaCl}$. The tubes were observed constantly for 6 minutes, then periodically for 2 hours and again at 24 hours.

Serotonin. One $\mathrm{ml}$ was centrifuged at $22,000 \mathrm{~g}$ for 10 minutes, and the platelets were frozen and thawed five times in $3.0 \mathrm{ml}$ of $0.02 \mathrm{~N}$ hydrochloric acid. The serotonin concentration of $2.0 \mathrm{ml}$ of the suspension was determined by a modified spectrophotofluorometric method (10) and was related to the protein concentration, which was measured on $0.5 \mathrm{ml}$ by the method of Sutherland, Cori, Haynes, and Olsen (11). Serotonin release was expressed as percentage of decrease in the treated platelets as compared to controls.

$A T P$. In six experiments $3.0-\mathrm{ml}$ portions of suspensions of platelets that had been incubated with thrombin, trypsin, or plasmin were centrifuged at $22,000 \mathrm{~g}$ for 10 minutes and the platelets lysed in $2.0 \mathrm{ml}$ of cold $3 \%$ trichloroacetic acid. The sediment was removed by centrifugation at $22,000 \mathrm{~g}$ for 10 minutes and the supernatant chromatographed on a Dowex 1 anion exchange column that was $4 \mathrm{~cm}$ long and $1.0 \mathrm{~cm}$ in diameter. Two $\mathrm{ml}$ of distilled water was added to the column after addition of the $2.0 \mathrm{ml}$ of supernatant. The acid-soluble nucleotides were isolated by intermittent gradient elution with $4.0-\mathrm{ml}$ volumes of formic acid and mixtures of formic acid and ammonium formate as described by Siekevitz and Potter (12). The procedure was modified to include elution with mixtures of $4.0 \mathrm{~N}$ formic acid with $1.0 \mathrm{M}$ and $4.0 \mathrm{M}$ ammonium formate. The eluates were read at $260 \mathrm{~m} \mu$ with a Beckman model DU spectrophotometer.

The activity of the streptokinase-activated plasminogen was measured by the method of Norman (13). The proteolytic (caseinolytic) activities of some of the enzymes were compared using a pH stat (14).

\section{Results}

Washed human blood platelets incubated with various concentrations of thrombin in the presence of EDTA did not aggregate or lyse during the incubation (Table I). Serotonin was released from the platelets by concentrations of thrombin that did not completely inactivate clottable protein. Higher concentrations of thrombin inactivated the clottable protein, and such platelets no longer aggregated when subsequently incubated with thrombin and calcium. Although slight morphologic variations were seen following incubation with thrombin, the platelets remained intact and retained the ability to produce retraction of clots when suspended in platelet-free plasma to which thrombin and calcium were then added. The addition of heparin following incubation with thrombin did not alter the results. However, the 
addition of heparin before incubation with thrombin completely inhibited the effects of thrombin.

Similar effects were found when washed platelets were incubated with trypsin (Table II). Substantial amounts of serotonin were released at concentrations of trypsin that did not completely inactivate the clottable protein. When clottable protein could no longer be demonstrated in the platelet lysate, the platelets did not aggregate when subsequently incubated with thrombin and calcium. Trypsin treatment did not interfere with the platelet's function in clot retraction. The re-

TABLE I

Effects of thrombin on platelets*

\begin{tabular}{ccccc}
\hline $\begin{array}{c}\text { Thrombin } \\
\text { concentration } \\
\begin{array}{c}\text { during } \\
\text { incubation }\end{array}\end{array}$ & $\begin{array}{c}\text { Serotonin } \\
\text { released }\end{array}$ & $\begin{array}{c}\text { Clottable } \\
\text { protein } \\
\text { following } \\
\text { incubation }\end{array}$ & $\begin{array}{c}\text { Aggregation } \\
\text { by subsequent } \\
\text { addition of } \\
\text { thrombin and } \\
\mathrm{CaCl}_{2} \dagger\end{array}$ & $\begin{array}{c}\text { Ability to } \\
\text { support clot } \\
\text { retraction } \\
\text { following } \\
\text { incubation }\end{array}$ \\
\hline$U / m l$ & $\%$ & & & $4+$ \\
0 & 0 & Present & $4+$ & $4+$ \\
0.02 & 0 & Present & $4+$ & $4+$ \\
0.2 & 65 & Present & $2+$ & $4+$ \\
2.0 & 80 & Absent & 0 & $4+$ \\
20.0 & 76 & Absent & 0 & $4+$ \\
200.0 & 74 & Absent & 0 & $4+$
\end{tabular}

* Twice washed platelets were incubated for 10 minutes at $37^{\circ} \mathrm{C}$ in Tris-buffered saline containing EDTA $(0.008 \mathrm{M})$ and thrombin in the concentrations indicated. Following incubation the platelets were washed twice in Tris-buffered saline containing EDTA $(0.0013 \mathrm{M})$ and the studies performed. The results were unchanged when heparin (200 $\mathrm{U}$ per $\mathrm{ml}$ ) was added after incubation to block thrombin action. The Table is a summary of six experiments. Serotonin release is the mean of three determinations at each concentration.

$\dagger$ Grading of aggregation: 0 , none; $1+$, few small clumps; $2+$, numerous small clumps; $3+$, many large clumps; $4+$, very large clump with few free platelets.

$\ddagger$ Grading of clot retraction: 0 , none; $1+$, separation of clot from wall of tube; $2+$, clot retracted to half the volume in the tube; $3+$, clot re tracted to one-quarter of the volume in the tube; $4+$, small retracted clot similar to control.

TABLE II

Effects of trypsin on platelets*

\begin{tabular}{ccccc}
\hline \hline $\begin{array}{c}\text { Trypsin } \\
\text { concentration } \\
\text { during } \\
\text { incubation }\end{array}$ & $\begin{array}{c}\text { Serotonin } \\
\text { released }\end{array}$ & $\begin{array}{c}\text { Clottable } \\
\text { protein } \\
\text { following } \\
\text { incubation }\end{array}$ & $\begin{array}{c}\text { Aggregation } \\
\text { by subsequent } \\
\text { addition of } \\
\text { thrombin and } \\
\text { CaCl }\end{array}$ & $\begin{array}{c}\text { Ability to } \\
\text { support clot } \\
\text { retraction } \\
\text { following } \\
\text { incubation }\end{array}$ \\
\hline$\mu g / m l$ & $\%$ & & & $4+$ \\
0 & 0 & Present & $4+$ & $4+$ \\
0.08 & 0 & Present & $4+$ & $4+$ \\
0.4 & 67 & Present & $4+$ & $4+$ \\
2.0 & 85 & Present & $2+$ & $4+$ \\
10.0 & 91 & Absent & 0 & $4+$ \\
50.0 & 91 & Absent & 0 & $4+$ \\
500.0 & 91 & Absent & 0 & $4+$ \\
\hline
\end{tabular}

* Twice washed platelets were incubated for 10 minutes at $37^{\circ} \mathrm{C}$ in EDTA Tris-buffered saline containing trypsin in the concentration indicated. Following incubation the platelets were washed twice in EDTA Tris-buffered saline and the studies performed. The addition Table is a summary of five experiments did not alter the results. The of three determinations at each concentration.
TABLE III

Effects of papain on platelets*

\begin{tabular}{|c|c|c|c|c|}
\hline $\begin{array}{c}\text { Papain } \\
\text { concentration } \\
\text { during } \\
\text { incubation }\end{array}$ & $\begin{array}{l}\text { Serotonin } \\
\text { released }\end{array}$ & $\begin{array}{l}\text { Clottable } \\
\text { protein } \\
\text { following } \\
\text { incubation }\end{array}$ & $\begin{array}{c}\text { Aggregation } \\
\text { by subsequent } \\
\text { addition of } \\
\text { thrombin and } \\
\mathrm{CaCl}_{2}\end{array}$ & $\begin{array}{l}\text { Ability to } \\
\text { support clot } \\
\text { retraction } \\
\text { following } \\
\text { incubation }\end{array}$ \\
\hline
\end{tabular}

$\begin{array}{crlll}\mu g / m l & \% & & & \\ 0 & 0 & \text { Present } & 4+ & 4+ \\ 0.32 & 19 & \text { Present } & 4+ & 4+ \\ 1.6 & 44 & \text { Present } & 2+ & 4+ \\ 8 & 61 & \text { Present } & 1+ & 4+ \\ 40 & 67 & \text { Absent } & 0 & 4+ \\ 400 & 82 & \text { Absent } & 0 & 4+\end{array}$

* Twice washed platelets were incubated for 10 minutes at $37^{\circ} \mathrm{C}$ in EDTA Tris-buffered saline containing papain in the concentrations indicated. Following incubation the platelets were washed twice in EDTA Tris-buffered saline and the studies performed. The Table is a summary of five experiments. Serotonin release is the mean of at least two determinations at each concentration.

TABLE IV

Effects of plasmin on platelets*

\begin{tabular}{|c|c|c|c|c|c|}
\hline \multicolumn{2}{|c|}{$\begin{array}{c}\text { Incubation } \\
\text { mixture }\end{array}$} & \multirow{2}{*}{$\begin{array}{l}\text { Serotonin } \\
\text { released }\end{array}$} & \multirow{2}{*}{$\begin{array}{l}\text { Clottable } \\
\text { protein } \\
\text { following } \\
\text { incubation }\end{array}$} & \multirow{2}{*}{$\begin{array}{c}\text { Aggregation } \\
\text { by subsequent } \\
\text { addition of } \\
\text { thrombin and } \\
\mathrm{CaCl} l_{2}\end{array}$} & \multirow{2}{*}{$\begin{array}{l}\text { Ability to } \\
\text { support clot } \\
\text { retraction } \\
\text { following } \\
\text { incubation }\end{array}$} \\
\hline Plasmin & $\overline{\text { Buffer }}$ & & & & \\
\hline$m l$ & $m l$ & $\%$ & & & \\
\hline 0 & 5.0 & 0 & Present & $4+$ & $4+$ \\
\hline 0.1 & 4.9 & 0 & Present & 0 & $4+$ \\
\hline 0.5 & 4.5 & 0 & Present & 0 & $4+$ \\
\hline 1.0 & 4.0 & 5 & Present & 0 & $4+$ \\
\hline 2.5 & 2.5 & 20 & Present & 0 & $4+$ \\
\hline 3.0 & 0 & 75 & Absent & 0 & $4+$ \\
\hline
\end{tabular}

* Twice washed platelets were incubated for 10 minutes at $37^{\circ} \mathrm{C}$ in EDTA Tris-buffered saline containing plasmin in the concentrations indicated. Following incubation $0.5 \mathrm{ml}$ bovine inhibitor or EACA (e aminocaproic acid) $250 \mathrm{mg}$ per ml was added. The platelets were washed twice in EDTA Tris-buffered saline and the studies performed. Clottable protein could not be demonstrated unless a plasmin inhibitor was added following incubation. The Table is a summary of seven experiments. Serotonin release is the mean of at least two determinations at each concentration.

sults were unchanged if a trypsin inhibitor was added following the incubation, but addition of the inhibitor before incubation completely inhibited trypsin action. Incubation of the platelets with comparable concentrations of papain produced equivalent effects (Table III).

In contrast, incubation of washed platelets with streptokinase-activated plasminogen up to a concentration of $10 \mathrm{mg}$ per $\mathrm{ml}$ did not completely inactivate the platelet clottable protein. Incubation of the platelets with dilutions of spontaneously activated plasmin also did not completely inactivate platelet clottable protein except when the platelets were suspended in the undiluted plasmin preparation (Table IV). In studies with plasmin it was necessary to add EACA or 
TABLE V

Fibrinolytic activity in lysates of platelets treated with plasmin*

\begin{tabular}{|c|c|c|c|c|c|}
\hline $\begin{array}{l}\text { Lysate from } \\
\text { control } \\
\text { platelets }\end{array}$ & $\begin{array}{c}\text { Thrombin } \\
1,000 \mathrm{U} / \mathrm{ml}\end{array}$ & $\begin{array}{l}\text { Saline } \\
0.9 \%\end{array}$ & $\begin{array}{l}\text { EACA } \\
0.4 \mathrm{M}\end{array}$ & $\begin{array}{l}\text { Lysate from } \\
\text { plasmin- } \\
\text { treated } \\
\text { platelets }\end{array}$ & $\begin{array}{l}\text { Lysis of } \\
\text { clot from } \\
\text { control } \\
\text { platelets }\end{array}$ \\
\hline$m l$ & $m l$ & $m l$ & \multirow{3}{*}{$\begin{array}{c}m l \\
0.02\end{array}$} & $m l$ & \multirow{3}{*}{$\begin{array}{l}\text { None } \\
\text { Complete }\end{array}$} \\
\hline 0.1 & 0.02 & & & 0.1 & \\
\hline 0.1 & 0.02 & 0.02 & & 0.1 & \\
\hline $\begin{array}{l}\text { Lysate from } \\
\text { control } \\
\text { platelets }\end{array}$ & $\begin{array}{l}\text { Saline } \\
0.9 \%\end{array}$ & $\begin{array}{l}\text { EACA } \\
0.4 \mathrm{M}\end{array}$ & $\begin{array}{l}\text { Lysate from } \\
\text { plasmin- } \\
\text { treated } \\
\text { platelets }\end{array}$ & $\begin{array}{l}\text { Thrombin } \\
1,000 \mathrm{U} / \mathrm{ml}\end{array}$ & $\begin{array}{c}\text { Clot } \\
\text { formation }\end{array}$ \\
\hline$m l$ & $m l$ & $m l$ & $m l$ & $m l$ & \\
\hline 0.1 & 0.02 & & 0.1 & 0.02 & None \\
\hline 0.1 & & 0.02 & 0.1 & 0.02 & Present \\
\hline
\end{tabular}

* In four experiments platelets that had been incubated in buffer alone or buffer containing streptokinase-activated plasminogen $(0.5 \mathrm{mg}$ per $\mathrm{ml})$ and washed twice with EDTA Tris-buffered saline were concentrated in $0.9 \% \mathrm{NaCl}$ and lysed by freezing and thawing. Upper: The supernatant from control platelets was clotted with thrombin. EACA or saline was layered on the clot and then lysate of plasmin-treated platelets was added. Lysis of the clot from control platelets occurred in the absence of EACA. Lower: EACA or saline was added to lysates of plasmin-treated platelets. Lysate of control platelets then was added. After addition of thrombin, clotting was inhibited in the absence of EACA.

bovine inhibitor to the platelet suspensions following incubation with plasmin and before freezing and thawing in order to demonstrate clottable protein in the lysate. Unless EACA or bovine inhibitor was present, lysates of plasmin-treated platelets prevented clot formation when added to

TABLE VI

Release of serotonin and ATP from plasmin-treated platelets by thrombin*

\begin{tabular}{ccc}
\hline & Control platelets & $\begin{array}{c}\text { Plasmin-treated } \\
\text { platelets }\end{array}$ \\
\hline $\begin{array}{c}\text { ATP } \\
\text { before } \\
\text { thrombin }\end{array}$ & $0.025 \mu$ moles $/ \mathrm{mg}$ & $0.021 \mu \mathrm{moles} / \mathrm{mg}$ \\
$\begin{array}{c}\text { ATP } \\
\text { after } \\
\text { thrombin }\end{array}$ & $0.010 \mu \mathrm{moles} / \mathrm{mg}$ & $0.008 \mu \mathrm{moles} / \mathrm{mg}$ \\
$\begin{array}{c}\text { Release } \\
\text { Serotonin } \\
\text { before } \\
\text { thrombin }\end{array}$ & $0.406 \mu \mathrm{g} / \mathrm{mg}$ & $0.406 \mu \mathrm{g} / \mathrm{mg}$ \\
$\begin{array}{c}\text { Serotonin } \\
\text { after } \\
\text { thrombin }\end{array}$ & $0.126 \mu \mathrm{g} / \mathrm{mg}$ & $0.222 \mu \mathrm{g} / \mathrm{mg}$ \\
$\begin{array}{c}\text { Release } \\
\text { Relo }\end{array}$ & $67 \%$ & $46 \%$ \\
\hline
\end{tabular}

* Twice washed platelets were incubated for 10 minutes at $37^{\circ} \mathrm{C}$ in $5.0 \mathrm{ml}$ of buffer or in $4.0 \mathrm{ml}$ of buffer containing $1.0 \mathrm{ml}$ of concentrated plasmin. Bovine plasmin inhibitor (Bayer $3380 \mathrm{RK}$ ) was added, and the platelets were washed twice in EDTA Tris-buffered saline. Thrombin and calcium were added to one portion of each of the control and plasmin-treated platelets. Control platelets aggregated, but plasmin-treated platelets did not. The platelets were sedimented, and serotonin and ATP were determined and related to platelet protein. lysates of control platelets, and they dissolved clots formed from lysates of control platelets (Table V). These results demonstrate that fibrinolytic activity was present in lysates of washed plasmin-treated platelets and furthermore indicate that although the clottable protein of the intact platelet was not completely inactivated by plasmin, this protein when freed from the platelet by freezing and thawing was inactivated by plasmin. Little or no serotonin was released from the platelets by incubation with either of the plasmin preparations except when the platelets were suspended directly in the spontaneously activated plasmin. Plasmin-treated platelets that contained clottable protein were not aggregated by addition of thrombin and calcium (Table IV), but did release serotonin and ATP (Table VI). The ability of the platelets to support clot retraction was not altered even after incubation in the undiluted plasmin (Table IV). Incubation of platelets with streptokinase alone produced no detectable alterations.

Incubation of the platelets with $\alpha$-chymotrypsin produced effects similar to the effects of plasmin (Table VII). Serotonin was released only after incubation with large amounts (1 to $5 \mathrm{mg}$ per $\mathrm{ml}$ ), and the clottable protein was not inactivated by concentrations that interfered with platelet aggregation. After incubation with concentrations of $\alpha$-chymotrypsin of $5 \mathrm{mg}$ per $\mathrm{ml}$, the clottable protein could not be demonstrated in the platelet 
lysate, but the platelets nevertheless functioned in clot retraction.

Carboxypeptidase, an enzyme that does not interfere with the clotting of plasma fibrinogen by thrombin (15), had no detectable effect on platelets in concentrations up to $5 \mathrm{mg}$ per $\mathrm{ml}$.

The proteolytic activities of some of the enzymes employed were compared by a caseinolytic assay. With $4 \%$ casein as substrate in a $\mathrm{pH}$ stat, approximately equivalent rates of hydrolysis were found for $25 \mu \mathrm{g}$ per $\mathrm{ml}$ trypsin, $10 \mathrm{mg}$ per $\mathrm{ml}$ streptokinase-activated plasminogen, and 500 $\mu \mathrm{g}$ per $\mathrm{ml} \alpha$-chymotrypsin. Thrombin had very little activity by this assay (Figure 1). ATP release from concentrated washed platelets was measured with comparable proteolytic concentrations of plasmin and trypsin and arbitrarily $25 \mathrm{U}$ per $\mathrm{ml}$ of thrombin. Plasmin released little ATP over a 30-minute incubation, whereas trypsin released substantial amounts. Thrombin released most of the ATP in a very short time (Figure 2).

\section{Discussion}

Normal platelets that contained clottable protein were aggregated by thrombin and calcium and when suspended in plasma displayed the
TABLE VII

Effects of $\alpha$-chymotrypsin on platelets*

\begin{tabular}{ccccc}
\hline \hline $\begin{array}{c}\alpha \text {-Chymotrypsin } \\
\text { concentration } \\
\text { during } \\
\text { incubation }\end{array}$ & $\begin{array}{c}\text { Serotonin } \\
\text { released }\end{array}$ & $\begin{array}{c}\text { Clottable } \\
\text { protein } \\
\text { following } \\
\text { incubation }\end{array}$ & $\begin{array}{c}\text { Aggregation } \\
\text { by subsequent } \\
\text { addition of } \\
\text { thrombin and } \\
\text { CaCl }\end{array}$ & $\begin{array}{c}\text { Ability to } \\
\text { support clot } \\
\text { retraction } \\
\text { following } \\
\text { incubation }\end{array}$ \\
\hline$\mu g / m l$ & $\%$ & & & \\
0 & 0 & Present & $4+$ & $4+$ \\
200 & 3 & Present & Trace & $4+$ \\
500 & 5 & Present & 0 & $4+$ \\
1,000 & 19 & Present & 0 & $4+$ \\
2,000 & 25 & Present & 0 & $4+$ \\
5,000 & 34 & Absent & 0 & $4+$ \\
\hline
\end{tabular}

* Twice washed platelets were incubated for 10 minutes at $37^{\circ} \mathrm{C}$ in EDTA Tris-buffered saline containing $\alpha$-chymotrypsin in the concentrations indicated. Following incubation the platelets were washed twice in EDTA Tris-buffered saline and the studies performed. The Table is a summary of nine experiments. Serotonin release is the mean of at least three determinations at each concentration.

changes associated with retraction of the clot. Platelets in which no clottable protein could be demonstrated after incubation with thrombin, trypsin, or papain were not aggregated by the subsequent addition of thrombin and calcium, but retained the ability to produce clot retraction when suspended in a medium containing fibrinogen. There was good correlation between the presence of clottable protein and the ability of platelets treated with these enzymes to be aggre-

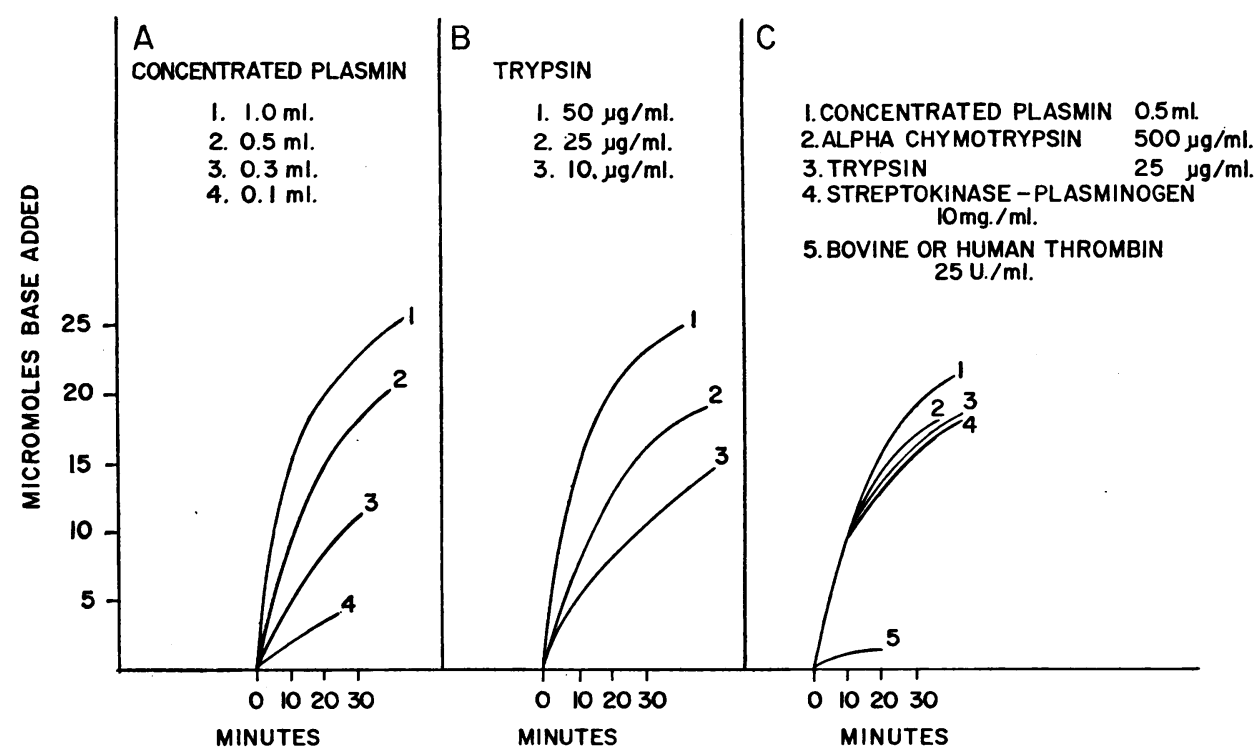

Fig. 1. Casein assay for proteolytic activity by pH stat. A). Four ml $4 \%$ casein was adjusted to $\mathrm{pH} 7.5$ at $37^{\circ} \mathrm{C}$, and spontaneously activated plasmin was added in the quantities shown. The curves recorded by the $\mathrm{pH}$ stat are demonstrated. B) Four $\mathrm{ml} 4 \%$ casein was adjusted to $\mathrm{pH} 7.5$ at $37^{\circ} \mathrm{C}$, and $0.1 \mathrm{ml}$ trypsin was added to give the final concentration shown. The curves recorded by the $\mathrm{pH}$ stat are demonstrated. C) This composite shows superimposed the curves obtained using comparable concentrations of the enzymes listed. 


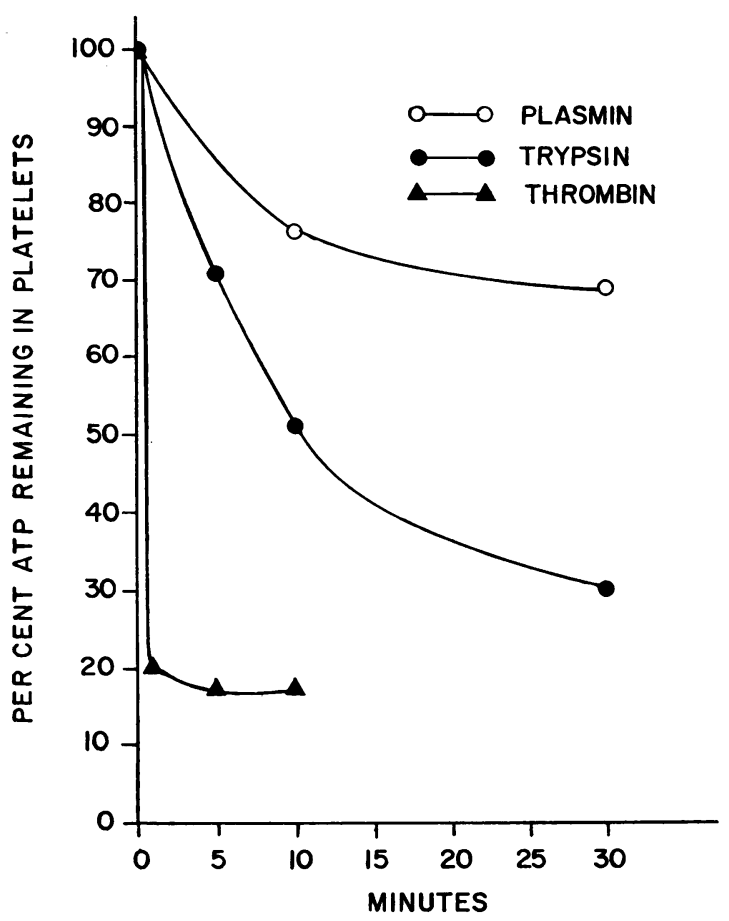

Fig. 2. ATP Release From platelets. In two experiments each, twice washed platelets were incubated for various times with thrombin, $25 \mathrm{U}$ per $\mathrm{ml}$; trypsin, $25 \mu \mathrm{g}$ per $\mathrm{ml}$; or spontaneously activated plasmin, $0.5 \mathrm{ml}$ in $4.5 \mathrm{ml}$ buffer. The reactions were stopped by adding the appropriate inhibitor; then the platelets were washed twice in $5 \mathrm{ml}$ EDTA Tris-buffered saline and divided for protein determination and chromatography of the adenosine nucleotides. The curves shown are an expression of the average ATP lost as compared with controls incubated without enzyme.

gated by thrombin. The clottable protein probably was not actually removed from the platelet by these enzymes, but was so altered that it no longer reacted to thrombin. It has been suggested that fibrinogen remains within enzymetreated platelets, since fluorescent antifibrinogen antibodies have been reported to react with trypsinized platelets and megakaryocytes (16). However, the lysed products of fibrinogen remain antigenically active $(17-19)$, and it is possible that antigenic portions of fibrinogen which are no longer clottable by thrombin remain associated with enzyme-treated platelets. Lysis of platelets by osmotic gradient releases fibrinogen into the medium, a phenomenon which has been interpreted to imply that fibrinogen is contained within the platelet (20). However, frozen and thawed lysates of platelets contain cellular debris and lipid particles even after ultracentrifugation (64,$000 \mathrm{~g}$ for 30 minutes), suggesting that membrane constituents remain in the supernatant fluid (21).

Relatively small concentrations of trypsin or thrombin were reported to release fibrinogen from high concentrations of porcine platelets when incubated at $25^{\circ} \mathrm{C}$, and the fibrinogen was observed to clot outside the platelet, suggesting that thrombin acts on a hitherto unknown protein on the platelet surface to release fibrinogen, which then clots (22). Our observations are at variance with these, possibly because of the different conditions of the experiments. The observation that trypsin inactivated the clottable protein suggests that fibrinogen was physically bound on the platelet surface (5). Trypsin is thought to react first with the same peptide bonds in fibrinogen as thrombin does $(14,15,23)$. Papain, which is known to clot plasma fibrinogen (24-26), produced effects on platelets similar to thrombin and trypsin. It seems possible that thrombin, trypsin, and papain alter the platelet membrane by acting in a similar manner on platelet fibrinogen.

Dilutions of plasmin and $\alpha$-chymotrypsin under the conditions employed did not eliminate clottable protein from platelets, but did inhibit aggregation of platelets by thrombin. Failure of plasmin to inactivate platelet fibrinogen cannot be attributed to lack of potency of the preparations, since rapid fibrinogenolysis occurred in plasmintreated platelets when the platelets were mechanically disrupted. It is possible that some of the platelet fibrinogen is incorporated in the platelet and is structurally protected from the action of plasmin. Furthermore, antiplasmin activity that has been reported to be associated with the platelet (27) may protect platelet fibrinogen from the effects of plasmin in the intact platelet. Fibrin degradation products have been reported to interfere with platelet aggregation, presumably by inhibiting the action of thrombin on fibrinogen (28). It seems unlikely that this observation would explain the inhibition of thrombin-induced aggregation by plasmin, since plasmin-treated platelets do react to thrombin by release of serotonin and ATP. The products of plasmin-digested fibrinogen have been shown to interfere with polymerization of plasma fibrinogen after thrombin action $(29,30)$ and with aggregation of platelets by thrombin (31), and it is conceiv- 
able that products of plasmin digestion adherent to the surface of the platelet might interfere with polymerization of platelet fibrinogen. Furthermore, plasmin itself digests fibrinogen into fragments that are not polymerized by thrombin (32). Thus, plasmin and $\alpha$-chymotrypsin possibly interfere with aggregation of platelets by thrombin by lysing bonds in platelet fibrinogen that are necessary for polymerization. However, other possibilities must be considered. These enzymes may inhibit aggregation of platelets by thrombin by effects on constituents of the platelet surface other than fibrinogen. Platelets from some patients with congenital afibrinogenemia lacked fibrinogen by immunochemical techniques, but were aggregated by thrombin and agglutinated by antifibrinogen antibody (33). Such platelets may contain either trace amounts of normal fibrinogen or another protein, possibly related to fibrinogen, which reacts with thrombin in the production of platelet aggregation.

It has been suggested that thrombin-induced aggregation of platelets is mediated through ADP (34). Plasmin-treated platelets contained almost normal amounts of ATP, which was released by addition of thrombin, yet these platelets did not aggregate. This observation does not eliminate the possibility that ADP may be involved in thrombin-induced aggregation, since plasmin treatment may have altered the platelet surface so that ADP had no effect.

Thrombin, trypsin, and papain, which removed clottable protein from platelets, also caused rapid release of serotonin from the platelets. Serotonin release, however, was regularly observed with concentrations of the enzymes that were too low to inactivate all of the clottable protein. It is possible that when platelet fibrinogen is enzymatically split, the platelet membrane may be so altered that intracellular constituents are allowed to escape even before all of the clottable protein has been inactivated.

Plasmin and $\alpha$-chymotrypsin in concentrations that interfered with aggregation of platelets by thrombin did not remove clottable protein or release serotonin from the platelets. Platelets treated with plasmin and $\alpha$-chymotrypsin did react to the subsequent addition of thrombin by release of serotonin. Fragments of plasmindigested fibrinogen that are unable to polymerize are nonetheless capable of being split by thrombin (32). Thus, thrombin may produce release of serotonin from plasmin-treated platelets by further splitting of plasmin-digested platelet fibrinogen. Alternatively release of serotonin from platelets by thrombin may not be due to an effect on platelet fibrinogen but may involve another mechanism. Platelets from certain patients with thrombocytopathic purpura have been found to be deficient in platelet fibrinogen, and platelets from these patients were not aggregated by thrombin, but did release serotonin and ATP following exposure to thrombin $(35,36)$.

Aggregation of platelets by thrombin appears to depend on a multiphase reaction involving platelet fibrinogen possibly involving polymerization of the fibrinogen. Release of serotonin and adenosine nucleotides by thrombin may depend only on proteolysis of platelet fibrinogen, but other mechanisms are possible.

\section{Summary}

Thrombin, trypsin, and papain inactivated the clottable protein of human blood platelets and released serotonin and ATP from the platelets. Platelets that did not contain clottable protein after treatment with these enzymes did not aggregate when subsequently incubated with thrombin and calcium, but retained their ability to support clot retraction when suspended in a medium containing fibrinogen.

Plasmin and $\alpha$-chymotrypsin in concentrations equivalent to trypsin in proteolytic activity did not inactivate the clottable protein or release significant amounts of serotonin or ATP from intact platelets although they rendered the clottable protein incoagulable in platelet lysates. Platelets treated with plasmin and $\alpha$-chymotrypsin in these concentrations did not aggregate but did release serotonin and ATP when subsequently incubated with thrombin and calcium.

The results are compatible with the hypothesis that platelet fibrinogen is a functional part of the structure of normal platelets.

\section{References}

1. Ware, A. G., J. L. Fahey, and W. H. Seegers. Platelet extracts, fibrin formation and interaction of purified prothrombin and thromboplastin. Amer. J. Physiol. 1948, 154, 140. 
2. Seligmann, M., B. Goudemand, A. Janin, J. Bernard, and P. Grabar. Etudes immunochemiques sur la présense de fibrinogène dans des extraits de plaquettes humaines lavées et dans certains extraits leucocytaires. Rev. Hémat. 1957, 12, 302.

3. Salmon, J., and Y. Bounameaux. Recherches sur l'antigénicité des plaquettes et du fibrinogène bovins. C. R. Soc. Biol. (Paris) 1956, 150, 2278.

4. Lüscher, E. F. Die Biochemie der Gerinnungsfaktoren der Thrombozyten. Fourth Int. Cong. Biochem. (Vienna) 1958, 10, 75.

5. Schmid, H. J., D. P. Jackson, and C. L. Conley. Mechanism of action of thrombin on platelets. J. clin. Invest. 1962, 41, 543.

6. Shermer, R. W., R. G. Mason, R. H. Wagner, and K. M. Brinkhous. Studies on thrombin-induced platelet agglutination. J. exp. Med. 1961, 114, 905.

7. Parmeggiani, A. Elektronenoptische Beobachtungen an menschlichen Blutplättchen während der viskösen Metamorphose. Thrombos. Diathes. haemorrh. (Stuttg.) 1961, 6, 517.

8. Kliman, A., L. A. Gaydos, L. R. Schroeder, and E. J. Freireich. Repeated plasmapheresis of blood donors as a source of platelets. Blood 1961, 18, 303.

9. Kline, D. L. Studies on the purification and activation of plasminogen (profibrinolysin). Yale J. Biol. Med. 1954, 26, 365.

10. Bogdanski, D. F., A. Pletscher, B. B. Brodie, and S. Udenfriend. Identification and assay of serotonin in brain. J. Pharmacol. 1956, 117, 82.

11. Sutherland, E. W., C. F. Cori, R. Haynes, and N. S. Olsen. Purification of the hyperglycemic-glycogenolytic factor from insulin and from gastric mucosa. J. biol. Chem. 1949, 180, 825.

12. Siekevitz, P., and V. R. Potter. Biochemical structure of mitochondria I. Intramitochondrial components and oxidative phosphorylation. J. biol. Chem. 1955, 215, 221.

13. Norman, P. S. Studies of the plasmin system. Measurement of human and animal plasminogen. Measurement of an activator in human serum. J. exp. Med. 1957, 106, 423.

14. Mihalyi, E., and J. E. Godfrey. Digestion of fibrinogen by trypsin: I. Kinetic studies of the reaction. Biochim. biophys. Acta (Amst.) 1963, 67, 73.

15. Pechet, L., and B. Alexander. The effect of certain proteolytic enzymes on the thrombin-fibrinogen interaction. Biochemistry 1962, 1, 875.

16. Gokcen, M., and E. Yunis. Fibrinogen as part of platelet structure. Nature (Lond.) 1964, 200, 590.

17. Berglund, G. Immunoelectrophoretic studies of fibrinogen, plasmin and lytic products of fibrinogen and fibrin. Int. Arch. Allergy 1962, 21, 193.

18. Salmon, J. Etudes immunochimique du fibrinogène et de ses dérivés. Clin. chim. Acta 1959, 4, 767.

19. Seligmann, M., and V. Nussenzweig. Etude immunochimique de la fibrinolyse. Proc. Eighth Cong. European Soc. Hemat. Basel, New York, Karger, 1962 , p. 210.
20. Buluk, K., T. Januszko, and M. Malofiejew. On the fibrinogen of blood platelets. Postepy Hig. Med. dósw. 1958, 12, 199.

21. Morse, E. E. Unpublished observations.

22. Grette, K. Studies on the mechanism of thrombincatalyzed hemostatic reactions in blood platelets. Acta physiol. scand. 1962, 56, (suppl. 195).

23. Alexander, B., L. Pechet, and A. Kliman. Proteolysis, fibrinolysis and coagulation. Significance in thrombolytic therapy. Circulation 1962, 26, 596.

24. Eagle, H., and T. N. Harris. Studies in blood coagulation. V. The coagulation of blood by proteolytic enzymes (trypsin, papain). J. gen. Physiol. 1937, $20,542$.

25. Steiner, R. F., and K. Laki. Light scattering studies on the clotting of fibrinogen. Arch. Biochem 1951, 34, 24.

26. Lorand, L., and K. Konishi. Papain-induced polymerization of fibrinogen. Biochemistry 1964, 3, 915.

27. Johnson, S. A., and C. L. Schneider. The existence of antifibrinolysin activity in platelets. Science 1953, 117, 229.

28. Kowarzyk, H., I. Glogowska, and S. Szymik. The enzymatic action of thrombin and the physical phase of fibrin clotting. Arch. Immunol. Ter. dósw. 1961, 9, 341.

29. Alkjaersig, N., A. P. Fletcher, and S. Sherry. Pathogenesis of the coagulation defect during pathological plasma proteolytic ("fibrinolytic") states. II. The significance, mechanism and consequences of defective fibrin polymerization. $\mathrm{J}$. clin. Invest. 1960, 41, 917.

30. Triantaphyllopoulos, D. C. Anticoagulant effect of incubated fibrinogen. Canad. J. Biochem. 1958, 36, 249.

31. Kowalski, E., M. Kopeć, and Z. Wegrzynowicz. Influence of fibrinogen degradation products (FDP) on platelet aggregation, adhesiveness and viscous metamorphosis. Thrombos. Diathes. haemorrh. (Stuttg.) 1964, 10, 406.

32. Wallén, $P$., and $K$. Bergström. Action of thrombin on plasmin digested fibrinogen. Acta chem. scand. 1958, 12, 574.

33. Gross, R., G. Schwick, N. Lang, D. Nies, B. Rahn, $M$. Becker, and $H$. Hengstmann. Untersuchungen an einer angeborenen Afibrinogenämie. Klin. Wschr. 1963, 41, 695.

34. Käser-Glanzmann, R., and E. F. Lüscher. The mechanism of platelet aggregation in relation to hemostasis. Thrombos. Diathes. haemorrh. (Stuttg.) 1962, 7, 480.

35. Jackson, D. P., E. E. Morse, P. D. Zieve, and C. L. Conley. Thrombocytopathic purpura associated with defective clot retraction and absence of platelet fibrinogen (abstract). Blood 1963, 22, 827.

36. Zucker, M. B. Platelet adhesion, release and aggregation. Thrombos. Diathes. haemorrh. (Stuttg.) 1964 (suppl. 13), p. 301. 